\title{
Incommunicado detention and torture in Spain, Part I: The Istanbul Protocol Project in the Basque Country
}

\author{
Istanbul Protocol Project in the Basque Country Working Group*
}

\begin{abstract}
There is increasing evidence to show that torture is a serious problem in the Basque Country. Whilst such evidence can be found in reports of international human rights monitoring bodies, sentences of Spanish and international courts, and empirical studies, they are limited in not having followed the Istanbul Protocol (IP) in order to evaluate the reliability of torture. A working group composed of professional associations of psychiatrists, psychologists, physicians and lawyers, in collaboration with the University of the Basque Country, conducted a four-year study on the medical and psychological consequences of torture in incommunicado detainees, including an assessment of credibility in line with the IP. The methodological design included a multi-level peerreviewed blind assessment and input by an external expert (from the Independent Forensic Expert Group facilitated by
\end{abstract}

\footnotetext{
^) Members: Agirre Inmaculada (Physician); Albi Inmaculada (Psychiatrist); Andueza Oihana (Psychologist); Arana Miren (Physician); Arnoso Maitane (Psychologist); Barrenetxea Olatz.

(Psychologist); Barrios Oihana (Psychologist); Callado LF (M.D., Ph.D.); Gandarias Itziar (Psychologist); García de Eulate Josefina (Psychologist); Gato Elena (Psychiatrist); Ibernia Maitane (Psychologist); Iturralde Matilde (Physician); Jordá Enric (Psychiatrist); Krakenberger Andres (Human Rights Expert); Landa Jon Mirena (Human Rights Expert); Legorburu Ixone (Psychologist); López de Luzuriaga Nagore (Psychologist); López-Neyra G (Psychologist);
}

International Rehabilitation Council for Torture Victims (IRCT)). A sample of 45 Basque people held in short-term incommunicado detention under anti-terrorist legislation (between 1980 and 2012) in Spain who had reported ill-treatment or torture was selected.

The findings are divided into four papers: the present introductory paper; the second analyses the credibility of the allegations of torture and introduces an innovative methodology that enhances the IP, the Standardized Evaluation Form (SEC); the third provides an analysis of the methods of torture and introduces the concept of Torturing Environments; and, in the last paper, the psychological and psychiatric consequences of incommunicado detention are analyzed. The collection of papers are intended to be useful not only in the documentation of torture in the Basque Country and Spain, but also as an innovative

Markez, Iñaki (Psychiatrist); Medina Elena (Psychiatrist); Moreno-Pérez Ana (Psychiatrist); Morentin Benito (Forensic Physician), NavarroLashayas Miguel Ángel (Psychologist); Pérez-Sales Pau (Psychiatrist); Plaza Mari Ángeles (Psychologist); Ruiz de Alegría Anabel; (Psychologist); Velasco Teresa (Psychologist); Vidal Luisa (Psychologist); Walther Marc (Psychiatrist); Zalbidea Urko (Psychologist), Zuazua Julene (Psychologist).

Correspondence to: morentin.b@aju.ej-gv.es

\footnotetext{
${ }^{i}$ Editor: Lilla Hárdi.
} 
example of how the IP can be used for research purposes.

Keywords: Istanbul Protocol, torture, ill-treatment, documentation of torture, Spain

\section{Torture in the Basque Country}

In cases of terrorism, the Spanish Criminal Procedure Code allows incommunicado detention, as provided by Articles 509, 520 bis and 527. These provisions set out that the maximum time of detention before presentation to a judge can be prolonged and basic rights of detainees that guarantee the physical integrity of the person under arrest, including the right to communicate with their families, lawyers or doctors of their choice, are curtailed. Far from shortening the period of five days of incommunicado detention as was unanimously demanded by international monitoring bodies, the reform introduced by Law 15/03 dated November 25th 2003 expands this period and includes the possibility of prolonging incommunicado detention for a further eight days in prison after being taken to court. Thus, this can lead to a total of 13 days of incommunicado detention. ${ }^{1}$

International organizations have expressed their concern about allegations made by detainees of torture and ill-treatment in Spain, especially in the context of incommunicado detention. In 2002, the United Nations Committee Against Torture (UNCAT) expressed concern about NGO reports. ${ }^{2}$ In 2004, the Special Rapporteur on torture and other cruel, inhuman or degrading treatment or punishment considered that in Spain, "Torture is more than sporadic and incidental." ${ }^{3}$ In 2008, the UN Human Rights Committee expressed concern that investigations were not being conducted properly and set out that "incommunicado detention must be abolished." ${ }^{4}$ In 2013, the
European Committee for the Prevention of Torture (CPT) concluded that there were "credible and consistent allegations of ill-treatment." 5

There have been many judgments condemning the Spanish authorities for lack of proper investigation into allegations of torture, including those made by the Spanish High Court, Supreme Court and Constitutional Court, the European Court of Human Rights, the United Nations Committee Against Torture, and the United Nations Human Rights Committee. ${ }^{4,6-10}$ They conclude that sufficient guarantees and supervision of incommunicado detention are substantially lacking, and condemn the absence of any effective investigation of complaints raised.

\section{Epidemiological data}

There are no official figures on how many people have been held in incommunicado detention and there is no official record of allegations of torture. The Basque NGO Euskal Memoria estimates that there have been approximately 10,000 cases of torture over the last 50 years, most allegations having been silenced and certainly never publicly denounced. ${ }^{11}$ According to an official report of the Basque Government (1960-2013), there are about 5,500 public allegations of torture (including both judicial complaints and extrajudicial allegations). ${ }^{12}$ In an empirical investigation, the Basque Government collected information regarding 634 cases of torture complaints during the period 2000-2008. ${ }^{13}$ Currently the Basque Government, in collaboration with the University of the Basque Country, is undertaking research about torture in the period 1960-2013 as part of the Peace and Coexistence Plan (Plan de Paz y Convivencia). ${ }^{14}$ Part of this research involves compiling a register of people who have alleged torture, the preliminary results 
of which suggested that there were more than 3,000 allegations of torture. ${ }^{15}$

Despite this evidence, the official position of the Spanish Government has been to deny the existence of torture, claiming that reports of torture were false and made systematically as part of the ETA strategy to undermine the Spanish criminal justice system. According to government figures, and based on cases where a decision has been reached, there are only anecdotal cases and torture cannot be considered an issue in Spain. ${ }^{16}$

\section{The Istanbul Protocol Project in the Basque Country (IPP-BC)}

Previous empirical studies have not used evaluations with international scientific tools regarding the reliability of the testimonies of torture in each particular case. With the objective of rectifying this deficiency in mind, a working group was created composed of seven different associations of psychiatrists, psychologists, physicians, lawyers and human rights workers in collaboration with the University of the Basque Country. ${ }^{\mathrm{i}}$ The team constituted over 30 professionals, mostly in the field of mental health. The Working Group worked on the basis of the following guidelines:

- Involve organizations and and a range of scientific groups in the field of health and human rights both locally and internationally.

- Carry out research using internationally

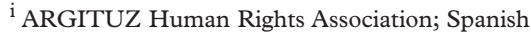
Association of Neuropsychiatry (AEN); Ekimen Elkartea Association for the Study of Social Problems; GAC Community Action Group, Resource Centre on Mental Health and Human Rights; Jaiki-Hadi, Prevention and Assistance Association; OME Osasun Mentalaren Elkartea. Mental Health and Community Psychiatry Association; SALDE Health Rights Association; Department of Social Psychology, Basque Country University (UPV/EHU).
}

accepted guidelines or forensic tools, validated for the assessment of physical and psychological torture, in line with the professional standards of good practice (the IP) and submit proposals to a Research Ethics Committee.

- Conduct a robust and rigorous methodological design (more than is usual in this type of study) to include an internal cross-validation procedure, scientific monitoring made by external institutions and international experts (see Part II).

- Extend the project to other local and state organizations working in areas of mental health and human rights.

All of these guidelines were met, as is demonstrated here and in Parts II to IV. For example, the project was approved by the Ethical Committee of Research at the University of the Basque Country and an expert from the Independent Forensic Expert Group, which is facilitated by the International Rehabilitation Council for Torture Victims, advised on the project (see Part II, Table 2).

A group of Basque people who had been held in short-term incommunicado detention under anti-terrorist legislation between 1980 and 2012 in Spain and who had reported ill-treatment or torture (whether or not such allegations were presented in court) was selected through a snowball sampling method using a Latin Square methodology to balance for gender, year of detention and state security force involved. The sample was composed of 45 incommunicado detainees. The working group conducted a four-year study on medical and psychological consequences of torture in these 45 subjects, including an assessment of the credibility of allegations in line with the IP.

Part II includes an analysis of the credibility of the allegations of ill-treatment 
or torture based on the highest international forensic standards in the field and a modified version of a new tool, the Standardized Evaluation Form (SEC), is proposed that strengthens the IP. Part III presents the data on methods of torture and it is suggested that further categories of psychological torture are needed in the IP. In the final paper, Part IV, data about the psychological and psychiatric consequences of short-term ill-treatment and torture in incommunicado detention is explored. Whilst it is acknowledged that the IP was not designed as a research tool, the findings show that the IP can indeed be very useful, not only in the documentation of torture but also in the field of scientific research.

\section{Dissemination and implications for the future}

The final data for each of the 45 participants were published in. ${ }^{\text {ii }}$ Preliminary results were also presented to the press and academic institutions in a workshop held in Madrid on September 18th 2014, as well as various organisations working with torture survivors (Reprive, Redress, Amnesty International in London and the World Organisation Against Torture (OMCT) in Geneva). The Special Rapporteur against torture and other cruel, inhuman or degrading treatment or punishment and the Special Rapporteur for Human Rights have also endorsed the project. The findings were also submitted to the United Nations sub-commitee for the prevention of torture and, in the Spanish political arena, were presented and discussed in the Basque Parliament. Importantly, the findings have also been shared with survivors and their relatives through individual and group meetings.

\footnotetext{
ii The final data for each of the 45 participants were published in the report "Incommunicado detention and torture. Assessments using the Istanbul protocol" 17
}

The experience gained by the professionals who have been involved in this work and the methodology used will be a valuable tool for future study, not least in analysing the data captured by the register of people who have alleged torture in the Basque Country as part of the Peace and Coexistence Plan ('Plan de Paz y Convivencia') commissioned by the Basque Government. ${ }^{14}$ It is intended that the experiences of a further 200 Basque incommunicado detainees who have alleged torture in the period 1960-2014 will be analysed. Additionally, this collection of scientific papers are intended to be useful, not only in the documentation of torture in the Basque Country and Spain, but also as an innovative example of how the IP can be used for research purposes.

\section{Acknowledgements}

The members of the Istanbul Protocol Project in the Basque Country Working Group wish to thank Felicitas Treue as a member of the International Rehabilitation Council for Torture Victims' Independent Forensic Expert Group who assisted with the methodology. Her support and advice was most valued. We also wish to thank Hans Draminsky Petersen who provided insightful comments and enthusiastic support at all stages of the process. 
References

1. Sunderland J. Spain, Setting an Example?: Counter-terrorism Measures in Spain. Human Rights Watch; 2005. [Internet] [Updated 2005 Jan 26] https://www.hrw.org/report/2005/01/26/settingexample/counter-terrorism-measures-spain

2. United Nations Committee against Torture (CAT): Spain. 23 December 2002, CAT/C/ $\mathrm{CR} / 29 / 3$.

3. United Nations Report of the Special Rapporteur on the question of torture: Visit to Spain. $6 \mathrm{Feb}-$ ruary 2004, E/CN.4/2004/56/Add. 2 .

4. United Nations Human Rights Committee. María Cruz Achabal Puertas v. Spain, Communication No. 1945/2010, U.N. Doc. CCPR/ C/107/D/1945/2010 (2013).

5. European Committee for the Prevention of Torture (CPT). Special recommendations after the visit of May 30 to June 13, 2011. Available from: http:/www.cpt.coe.int/documents/ esp/2013-06-inf-esp.pdf. See also all other reports on Spain available from: http://www.cpt. coe.int/).

6. Sentencia de la Audiencia Nacional de 12 abril de 2010 relativa al denominado "Caso Egunkaria”. Audiencia Nacional, Sala de lo Penal Sección Primera SENTENCIA Núm. 27/2010. Available from: http://www.berria.eus/dokumentuak/dokumentua599.pdf

7. Sentencia del Tribunal Supremo 483/2011, de 30 de mayo, que revisa en casación un supuesto de colaboración con organización terrorista del año 2009.

8. Tribunal Constitucional (STC 63/2010, de 18 de octubre de 2010). Available from: https:// www.boe.es/diario_boe/txt.php?id=BOEA-2010-17740

9. European Court of Human Rights. Beortegui Martinez v. Spain (no. 36286/14). 31 May 2016

10. United Nations Committee against Torture (CAT). Communication no. 453/2011. Decision adopted by the Committee at its 48 th session, 7 May to 1 June 2012.

11. Arzuaga, Julen, Oso Latza izan da. Tortura Euskal Herrian. [It has been so tough. Torture in the Basque Country] Euskal Memoria, DonostiaSan Sebastian; 2012.

12. Basque Government, Presidency. "Informe-base de vulneraciones de derechos humanos en el caso vasco (1960-2013)" [Base-Report of Human Rights Violations in the Basque Country (19602013)]. Vitoria-Gasteiz, 2013; June.

13. Human Rights Department. Torture: a scientific approach (2000-2008). Basque Government, Vitoria-Gasteiz; 2009.
14. Basque Government, Presidency. Lehendakaritza, Secretaría General de Paz y Convivencia. Plan de paz y convivencia 2013-16 [Peace and Coexistence Plan] Gobierno Vasco, June; 2013.

15. Instituto Vasco de Criminología. Proyecto de investigación de la tortura en Euskadi entre 1960-2010: Informe preliminar sobre diseño y primeros pasos del estudio sobre la tortura. Donosti 2015. Available from: http://www.nuevatribuna.es/media/nuevatribuna/files/2015/06/26/ informe_estudio_tortura_parlamento_vasco.pdf).

16. Spanish Government answer to CPT ON the Report on its visit dated September 9th to October 1st 2007: CPT/Inf (2011) 12. Available from: http://www.cpt.coe.int/documents/esp/2013-06inf-eng.htm

17. Argituz, AEN, Ekimen Elkartea, GAC, JaikiHadi, OME, OSALDE, Departamento de Psicología Social (UPV/EHU). Incommunicado detention and torture. Assessments using the Istanbul protocol. Bilbao: Ekimen Ed. and Irredentos Libros; 2014. Available from: http:// www.psicosocial.net/images/Tortura/InformeIncomunicacion-tortura-Analisis-protocoloEstambul-Eng.pdf, or can be requested from the corresponding author. 